\section{COMPETING DISCOURSES \\ ON HILLTRIBES: MEDIA REPRESENTATION OF ETHNIC MINORITIES IN THAILAND ${ }^{1}$}

\section{Krisadawan Hongladarom ${ }^{2}$}

\section{Introduction}

Ethnic minorities in Northern Thailand have been characterized as hill dwellers who grow opium and make a living from

1 This paper is part of the research project "Discourses on ethnic minorities in Thailand: A study of the relationship between language and ideology," supported by the Silver Jubilee Fund, Chulalongkorn University. I am grateful to Chulalongkorn University for the research grant and for the financial aid which allows me to present this paper at the 7 th International Conference on Thai Studies (ICTS7) in Amsterdam on July 4-8, 1999. I would like to thank several newspaper editors and columnists who kindly answered my questions. I thank Niramol Methisuwakul and her Thung Saeng Tawan team for an insightful discussion and for the video-copying of productions on hilltribes. I am grateful to Theraphan Luangthongkum and audiences of the seminar at the Institute for Thai Studies held on 30 April 1999 for their suggestions. This paper has also benefited from the comments made by Ubonrat Siriyuwasak, Duncan McCargo, and other panellists in the panel Media, Cultural politics, and the Nation State at the ICTS7. Last but not least, I thank Sinee Wanichanond and particularly Soraj Hongladarom for their help.

2 Ph.D., Lecturer, Department of Linguistics, Faculty of Arts, Chulalongkorn University, Bangkok, Thailand slash-and-burn farming. ${ }^{3}$ The terms chao khao 'hilltribe people' or 'mountain people,' chaothai phukhao 'hilltribal Thai,' and rasadorn thai phukhao 'hilltribal Thai citizens' call upon such names as Lahu, Akha, Lisu, Hmong, Yao, or Karen, though the latter group do not usually live in the highlands. ${ }^{4}$ Like ethnic minorities

3 This piece of knowledge, or what I prefer to call "ethnic stereotype," appears even in a list of questions usually asked in examinations. One such question for Pathom Five (Grade 5) pupils prepared by a private school is as follows:

-Which of the following cannot be considered a cause of deforestation?

a. Capitalists illegally fell trees.

b.Chao khao do slash-and-burn farming.

c. Villagers clear forests and make a living on the land.

d. No law punishes wrongdoers.

The expected answer is choice (d). So hilltribe people, along with capitalists and villagers, are remembered as agents of deforestation. Note that there is no race or ethnicity attached to the words capitalists or villagers, whereas the term chao khao denotes non-Thai Northern minorities.

4 Another recent term to refer to hilltribe people is khon chay khorp 'people at the margin'. This term was coined by and is used among academic circles and NGOs but hardly appears in the media or in government discourse. 
in other nation-states, these groups are subject to stereotypes formed by dominant groups. The stereotypes are expressed in parent talk during socialization, children's books, school textbooks, news and advertising in the press and on TV, parliamentary debates, and other forms of public discourse (van Dijk et al 1997:164). Hilltribe people are often represented in these discourses as the other who are different from Thais, full-fledged citizens of the nation-state in terms of race, language, customs, and culture. Because of their values, some of which seem to oppose those of the nation-state, distinctive patterns of life, and remote place of residence, they are often regarded as agents of deforestation, narcotic trafficking, and other criminal activities, especially when these activities take place near the border.

During this past decade there has been a lot of information on hilltribes in the mass media. Literature on hilltribes, among which are translations of personal narratives and folktales from the native languages into Thai, is emerging in an impressive quantity. Stories of hilltribes also appear in cultural magazines such as Silapa Wattanatham, Sarakhadi, the Earth, Muang Boran, and Siam Araya. But the most influential sources of knowledge about hilltribes are popular newspapers such as Thai Rath, Khao Sod, Matichon, Daily News, and a few business newspapers whose target readership is the middle class. The. most outspoken of the latter type are Phujadkan Raiwan and Krungthep Thurakit. These newspapers believe that their factual reports have a strong impact on society. ${ }^{5}$

Thung Saeng Tawan (Sunshine Field) is one of a number of recent television programs which have reported on the striking ways of life of tribal minorities. Visual images of green fields, elaborate rituals, traditional costumes, and innocent faces of chao khao children stress the importance of preserving these varied cultures. They also stimulate an awareness that these people live in the same nationstate as Thais, and that the latter can learn a lot from their wisdom. Actually, there have been several TV programs and documentary films broadcast on TV which feature hilltribe stories, but

5 The news report on 4 August 1998 in Phujadkaa Raiwan illustrates this position well. According to the news, the newspaper sent a team to Wat Tham Krabok, whose Hmong residents were kept an eye upon by local authorities for fear that they would be involved in drug trafficking or other illegal activities. The report stresses an important goal of the newspaper, which is to search for the truth concerning this group of Hmong and to report what actually happened. It also emphasized the fact that what the newspaper reported had a strong impact on the authorities. They agreed to release some Hmong who had been put in jail. The following caption describes a picture of two Hmong girls holding her two baby brothers. They are surrounded by three other unhappy looking siblings. All were just released from jail:

All the seven children of Mr. Jong and Mrs. Bao Sae Hur, who were indicted with severn charges, have been released after "Phujadkan" presented the news and Tak MP agreed to bail out father, mother, and their children caught in jail. 
Thung Saeng Tawan is quite unique in the sense that its main goal is neither to present tribal minorities as objects of tourism nor to be a government mouthpiece in publicizing what the state does for these people. To me, one of the most important objectives of the program is to present a positive image of the hilltribes as people who care for the environment and are entitled to land-use rights and the right to Thai citizenship.

My interest in media discourse stems from previous works such as Kress and Hodge (1979), Fairclough (1992, 1995), Kuusisto and Östman (1997), van Dijk (1995), Blommaert (1997), and Mehan (1997), which are based on the assumption that public discourse is an instrument of ideology and that discourse not only reflects reality but constructs and shapes it in the way its producers want it to be. ${ }^{6}$

${ }^{6}$ Blommaert (1997:7) argues that definitions of language should include the interwovennesss with society, and the scope of language studies should include concerns that are far removed from its traditional restricted domain. He asserts that linguists should pay attention to the field of language politics and give more theoretical contributions to this field. Language politics - the articulation of ideologies, to quote Silverstein (1979), encompasses various kinds of discourses ranging from political rhetoric to media discourse, institutional discourse and racism. Discourse is an important aspect of social life which reveals under what discursive practices people talk about one another, how discourse relates to power, and how it constitutes knowledge (Foucault 1972). In other words, discourse is not simply an extended sample of speech with fixed rules of usage, a product of scrutiny by linguists alone.
Following van Dijk (1995:243), ideologies are defined here as fundamental systems of social cognitions shared by members of social groups. ${ }^{7}$ The notions attitude, knowledge, value, perspective, and stereotype possess both social and cognitive aspects and are subsumed under the broader term of ideology.

This paper builds upon the body of knowledge on the relations between discourse and ideology. It demonstrates how ideologies are conveyed through linguistic strategies, such as the use of certain words, preference of certain grammatical structures, and foregrounding of certain information. For example, passivization (presenting $\mathrm{Y}$ as a patient and demoting $X$ into an implicit agent position or omitting it entirely) is among the devices which convey the speaker's viewpoint concerning who should be responsible for an incident and who is affected by the action described. The study of media discourse thus provides strong linguistic evidence that news is not simply reported; it is a culmination of perspectives and stereotypes. In other words, journalists not only write the news;

${ }^{7}$ In elaboration, van Dijk (1995:248) writes: Ideologies are basic frameworks of social cognition, shared by members of social groups, constituted by relevant selections of sociocultural values, and organized by an ideological schema that represents the selfdefinition of a group. Besides their social function of sustaining the interests of groups, ideologies have the cognitive function of organizing the social representations (attitudes, knowledge) of the group, and thus indirectly monitor the group-related social practices, and hence also the text and talk of its members. 
they construct it. The process of construction which occurs daily inevitably has a strong influence on the conception of people in a wide scale. If the media has negative attitudes towards ethnic minorities, the views manifested in what they write guide consumers' attitudes and behaviors towards these ethnic groups.

In this paper I try to explicate ideologies relating to hilltribe people in media discourse. The major argument is that there are conflicting views on these minorities as expressed or manifested in newspaper reports and television programs. The paper addresses the following questions: (1) what can be concluded about the ways journalists write, talk, and tell stories about hilltribe people, (2) what specific semantic/lexical and discursive strategies are employed, and (3) what contrastive ideologies can be derived from the different sources of "talks" about these ethnic groups. Specifically, the paper examines "ideological transformations of discourse," to use Lee's (1992) term, involving Hmong and Karen. It pays special attention to the discourse which presents them as citizens in the nationstate, in comparison with the one which presents them as aliens or enemies. ${ }^{8}$

8 The term 'citizen' here is used to designate the word pholamuang in Thai, in comparison with the word rasadorn, which connotes the sense of being a subject of a country, as Archavanitkul et al (1999: xxxii) remarks: "Rasadorn tends to view itself as a lonely person who awaits help from the senior and powerful (phu yai)...At the same time, citizens demand a greater say, have a sense of duty visa-vis society, have a public sense, are able to think freely, to take responsibility and to

\section{Data and Scope of the Study}

This work is a preliminary analysis of media representation of hilltribe people. It is based on data drawn from front page news and opinion articles in daily newspapers. The materials in Thai form the basis of the analysis. This is because I think the data in Thai reflect perspectives and attitudes of Thais, the dominant group, towards the other more clearly than those in English. Given the limited time and scope of the work, I was unable to compare and contrast ideologies manifested in Thai daily newspapers and English ones, or those in the country's two major English newspapers: the Bangkok Post and the Nation. These should have revealed more interesting insights.

My original intention was to analyze news reports based on a 10-year frame which I believe would help us to see transformations of ideas and attitudes of the media (and in implication those of people in the nationstate) towards minorities. But this has proved too ambitious for this present paper. Thus I have chosen to restrict my analysis to recent news articles, particularly those covering events in 1998, when narcotics allegations brought the Hmong at Phop Phra district, Tak province and at Wat Tham Krabok, Saraburi province into the limelight. The news discourse on the Hmong as well as on the Lahu or Museur and the Karen clearly reflects the attitudes of the newspapers towards hilltribe people in general and these specific groups in particular.

recognize the need for making sacrifices for the public good." Interestingly, in official reports hilltribe people are often referred to as rasadorn thai phukhao, and never pholamuang thai phukhao. 
Another source of data which represents a competing view on ethnic minorities is Thung Saeng Tawan. I have chosen this TV program because it represents ethnic minorities in a creative and interesting way, and its discourse on hilltribes is in sharp contrast with the news discourse. What is unique about Thung Saeng Tawan is that children are the main participants. They tell stories, take viewers to their homes, and tell TV reporters of their hopes, dreams, and fears. The program originated in 1991 and since that time, there have been 24 episodes, featuring stories on the Karen, Akha, Lahu, Yao, and Hmong. Of all these, I focus on the Karen, as most of the episodes are about them, and these clearly reflect the ideology that hilltribe people are not agents of deforestation. On the contrary, they are, as one journalist calls them, nakanurak 'conservationists'.

In addition to the newspaper and television discourses mentioned above, I include data from informal interviews with newspaper columnists and editors as well as with TV producers. These interviews help reveal covert attitudes and stereotypes and complement what is represented in the press.

\section{The News Discourse on Hilltribes}

When asked which news events concerning hilltribe people have been big issues in the media, most journalists whom we interviewed cited the political problem with Karen rebels along the ThaiBurma border and the problem with amphetamines associated with the
Hmong. 9 To one journalist, the name Karen refers to a war in Burma, and Hmong to opium and drugs. Front page news about hilltribe people has been dominated by issues of concern for the well-being of the nation, such as deforestation, drug trafficking, border unrest, and national security. Recently, issues having a direct impact on urbanites, viz murder and illegal labor, have captured the media's attention. ${ }^{10}$ These latter issues depict Karen as well as Burmese as robbers and murderers. These two groups of people have migrated to big cities and work as maids and factory workers. Several newspapers have paid attention to this type of news. Matichon, for example, covered the incident in which a Karen killed the mother of the newspaper's executive editor in consecutive issues over a period of several weeks in August 1998. This may be because of the nature of murder stories in general, frequently generate considerable consumer interest, and because of the feeling that these people are to blame. A journalist remarks: "They committed a

\footnotetext{
${ }^{9}$ See Rajah (1990) for a profound analysis of news on Karen separatists drawn from the Bangkok Post in May 1989.

10 According to van Dijk et al (1997), the discourse on other ethnic groups is often dominated by such 'ethnic topics' as immigration, crime, cultural differences and deviance, discrimination and socioeconomic problems. On the contrary, the discourse about 'us' is not limited only to this short list; it enjoys a variety of topics. This is exactly the situation we find in Thailand. But as will be seen in the remainder of the paper, some Thai media groups also perceive hilltribes as part of their community, thus viewing them from the 'us' perspective.
} 
crime on Thai soil without feeling grateful to Thailand for letting them stay here".

In fact, at present there are two groups of Karens and two groups of Hmongs living in Thailand: those who have lived in the northern highlands of Thailand for a long time and those who, because of political unrest in their home countries (Burma and Laos respectively), immigrated to Thailand several years ago. Thais, in general, do not perceive the first group as villains or as people who they cannot be trusted. Instead, they look at these people as ignorant tribes who do not know how to assimilate to the mainstream. It is only recently that these attitudes have begun to change. ${ }^{11}$ The Karen are labelled 'separatists,' and the Hmong 'drug traffickers.' The two groups are classified as 'immigrants,' 'refugees,' 'aliens,' and 'displaced persons.' Because of these labels, it is easy to understand why Karen and Hmong are often treated with disdain and are associated with such problems as illegal labor, robbery, and drug trafficking. It must also be noted that these latter groups of Karen and Hmong are classified as belonging to the same group as chao khao. Therefore, what we read and hear about hilltribes these days tends to deal with these urban problems more than with traditional ones, i.e., environmental destruction, land encroachment, and opium distribution.

There was news about the Hmong more often than about other tribal minorities in 1998. The Hmong are represented as

11 I would like to thank Theraphan Luangthongkum for sharing this insight with me. forest invaders and drug traffickers. These representations, as I will argue below, are based on the conception that they, as well as other tribes, are enemies of the state. Even though there are voices which oppose this ideology, they belong mostly to non-journalists and are not loud enough. They are reported on the inside of the newspapers which are harder to see and not so fun to read, when compared to front page news.

\section{The Hmong as Forest Invaders}

Among all the tribes in Northern Thailand, the Hmong are the group which gains the most distrust from the Thai authorities. When members of the Network of Northern Farmers comprising representatives from six tribes (i.e., Hmong, Lisu, Lahu, Akha, Karen and Mian (Yao)) lodged a petition urging the government to remove a cabinet resolution to remove hilltribe villagers from forests, only the Hmong were blamed for the action. The petition confirmed that these people "should be closely watched," for they are considered "extremists" and their number is "rising at an alarm rate" (Bangkok Post, 31 July 1998 "Policy Review Sought On Giving Nationality Due to Hmong Criminal Activity"). Note the hidden violence in the word extremist and the fright conveyed by the latter expression.

Hmong have been depicted as one of the "big agents of deforestation," as can be seen in the following news report (Matichon, 22 June 1996): 
(1)

"Hmong" Invaded Conserved
Forests
Serious - Unresolvable Problem of
Muang Kluay Khai ${ }^{12}$

The report is based on the voice of the deputy governor of Kampaeng Phet, which is explicit in the headline and in the caption beneath one of the two accompanying pictures. The report begins with a description of Baan Paa Khaa as a remote village in a deep valley (Paragraphs 1-4), followed by a description of these chaothai phukhao 'mountain Thai people' and their simple way of life based on farming (Paragraphs 5-6). The remainder of the report focuses on what the officials discovered-areas within the national forest were invaded and destroyed, and what needs to be done-to relocate these people to the lowlands.

It is clear that the news is written from the viewpoint that the Hmong are wrongdoers. Their crime is presented in the headline framed in a transitive clause with Hmong highlighted as the sole agent of deforestation. Under the first of the two accompanying pictures, a caption, expressed in the passive voice, asserts this illegal act: "The green and abundant Ban $\mathrm{Pa}$ Kha valley is being invaded by the Hmong hilltribe". Throughout the text, Hmong are referred to as chao khao. This is the most common term of reference for the Hmong as well as for other

12 Muang kluay khai literally means town of finger banana, which is a symbol of Kampaeng Phet. This province is renowned for this kind of banana. tribal groups in media discourse. In other words, the names Hmong, Karen, Lahu, and others are interchangeable in this discourse. These hilltribe people are often classified as if they were a homogeneous group: they are the chao khao, who are different from the rest of the population .

Attajak Satayanuraksa (1998) comments that if a lowland Thai is arrested on drug trafficking charges, the newspapers may report that $\mathrm{Mr}$. X or Ms. Y is involved in the trafficking. But when ethnic minorities are arrested, they are represented as a group. Because they are ethnic minorities, when they commit a crime, the offense is more serious. Attajak's observation is confirmed by the following news headline and extract appearing in Suethurakit (21 June 1997):

Governor Announces Firm Action Against People Who Invaded Chong Mek

A new group of citizens made an invasion again. The province announced that their buildings be removed by 23 June. If they refuse to leave, the province will take strong legal actions. (Paragraph 2)

The non-pejorative word prachachon 'people, population' appears in the headline, and the word rasadorn 'citizen, subject' is used throughout the text, emphasizing that these wrongdoers are citizens of the country who are ignorant of the laws. The last sentence indicates that if these people do not comply with the order, the province, as law keeper, will do something about it. 
This news report is in sharp contrast with the one below, which appeared in the Thai Post on 28 March 1997:

\section{Hunt Black Museur Who Invaded} Conserved Forests

Phayao - Let's hunt a group of Black Museur hilltribe people who invaded conserved forests hoping to settle and make a living there. If arrested, they will be sent back to where they came from because they have been found to have dubious conduct. Some people always send them food. It's feared that they will come to cut trees and cause a great damage again. (Paragraph 1)

Although this report does not concern the Hmong, it reproduces the same messagehilltribe people are forest invaders. To me, this report is embedded with the feelings of distrust and hatred. The headline and the first line in the text are expressed in the imperative mood urging readers to take part in the process of "hunting" hilltribe wrongdoers. Note the use of the word 'again' at the end of the last sentence, which presupposes that this specific group has committed this crime before. Moreover, when we compare this news article with the one in (2), we see that the offense of the Black Museur is more serious than the one committed by Thai. Thai are being urged to remove their buildings from the land they claimed; Museur are being hunted, and will be arrested and sent back to where they came from. In addition, as Museur, or Lahuthe name they call themselves - is not a familiar name to most Thai, the modifying dam 'black' augments feelings of distrust and fear.

Reports like this one and the ones mentioned above clearly illustrate the fact that hilltribe people are still perceived as those who destroy the forests.

\section{The Hmong as Drug Traffickers}

Drug trafficking became one of the most serious issues concerning the Hmong, whose identity has always been associated with opium growing (Tapp 1990). Three Hmong men from Phop Phra district, Tak province were arrested for amphetamines possession in July 1998. Asking for the release of these men, a number of Hmong residents from Phop Phra went to a police station in the province, and this is how the riot reported in (4) began. Interestingly, the conflict is depicted as one between highlanders and lowlanders, instead of one between minorities and the state. The following report illustrates how Hmong are portrayed as agents of unrest and how they challenge the authorities. Note the term herm 'bold, arrogant' used to characterize this ethnic group.

Hit Police Almost Dead

Arrogant 'Hmong' invade and destroy Police Station Second Time

(Siam Rath, 18 July 1998)

After only one night arrogant Hmong rounded up more than 300 people to reinvade a Phop Phra police station. This time they used sticks to beat policemen almost dead. (Police) seized gun weapons and transmitters....It's feared that 
Competing Discourses on Hilltribes: Media Representation of Ethnic Minorities in Thailand

this will become a big problem between lowlanders and highlanders.

Using transitive clauses with Hmong in the subject position and policemen in the direct object position, the news writer depicts the former as agents of unrest and the latter as those suffering from the violent and deadly acts committed by the former. Upon reading this news article, readers cannot help but feel that the Hmong are insensible and that they may have been engaged in a political movement of some kind; otherwise, they would not have possessed weapons.

The following list of headlines in Thai daily newspapers in July 1998 alone illustrates how frightening the incident appears in the press and what attitudes the press have towards this minority group (the number in parenthesis refers to the date in which the article appeared in the newspaper). ${ }^{13}$

Hmong Surround Tak Police Station Snatching the Accused (Matichon 18)

Hit Police Almost Dead: Arrogant 'Hmong' Invade and Destroy Police Station Second Time (Siam Rath 18)

Fear "Hmong" to Rebel and Make Trouble (Daily News 19)

13 I must admit that the texture of the original versions is missing in the translations of these headlines. The translations only give rough ideas of the representations.
Hmong Leaders Transferred to Bangkok Jail (Matichon 19)

"Hmong" Arrested: Movement Spreads to Other Provinces War Weapons on Hand in Clash with Police (Matichon 20)

Border Control Police Asked to Help Tak Police Keep an Eye on Hmong (Matichon 22)

Hmong Challenge Authorities, Shooting Thai (Siam Rath 25)

Prepare to Invade Hmong Stronghold, Tham Krabok (Khaw Sod 29)

Trace Hmong Past, "Warriors of Opium War" (Thai Rath 29)

US Intervenes Asking Chuan Not to Relocate Tham Krabok Hmong (Matichon 30)

Crackdown on Hmong War Storage in Center of Town (Khaw Sod 30 )

Tham Krabok Temple Investigated for Involvement with Amphetamine Hmong (Thai Rath 31)

In this list of news reports which span a period of two weeks, Hmong are shown to be extremely violent. They destroyed a police station, hit policemen, formed a movement, possessed war weapons and prepared to use them to clash with the police, and were involved in drug trafficking. 
It is interesting to note that the discourse of the Phop Phra incident shifts its focus from the Phop Phra Hmong to those at Wat Tham Krabok from 29 July onwards. This is how amphetamines are tied up with such issues as illegal aliens, war weapons, resistance movements, and even the Communist Party of Thailand. ${ }^{14}$ The headline in Khaw Sod names Wat Tham Krabok a Hmong stronghold. The term 'stronghold' is a translation of the Thai term rang 'nest, home (colloquial)' used in the expressions: rang nok 'bird's nest,' klap rang 'return home,'rang jone 'bandit's nest/center'. Therefore, calling Wat Tham Krabok, where several thousands Hmong are currently residing, rang does suggest that this group of people who have taken refuge in Thailand may abuse this temple as a center of illegal activities.

Several negative labels have been created to refer to the Hmong at Phop Phra and those at Tham Krabok. These terms presuppose that there are pre-established social categories. For example, the Hmong are characterized as "amphetamine Hmong," "amphetamine selling Hmong," or even "amphetamine trading Hmong gang," and "drug trafficking Hmong gang". Hmong are also referred to as "Phop Phra Movement" instead of "Phop Phra Hmong" (Khaw Sod, 30 July 1998). Note that the term Phop Phra in this metonymic phrase stands for the whole ethnic group of Hmong. Interestingly, the media never

14 According to Tapp (1989:19), one of the stereotypes Hmong have faced is that they are opium-producing 'komunit' (the Thai colloquialism for 'communist'). call Thai "amphetamine Thai," or "drug trafficking Thai," though we may anticipate that the labels would be applied to other ethnic minorities if they are involved in these illegal activities.

As expected, these incidents are reported mainly from the authorities' perspectives. It is therefore not surprising to see that Hmong are represented as "arrogant and violence seeking," and "ungrateful people who create a lot of problem on Thai soil". In addition, there is hardly any serious distinction between Hmong who have settled long ago, including those at Phop $\mathrm{Phra}$, and those who immigrated from Laos and settled at Wat Tham Krabok quite recently. The categories 'citizens' and 'immigrants'/'refugees' merge into one becoming the notorious amphetamine Hmong.

The news report with the headline in (6) clearly illustrates the media's negative attitudes towards Hmong.

Hmong's Past Traced, "Warriors of Opium War"

(Thai Rath, 29 July 98)

There are several interesting features in this article which point to the ideology that Hmong are enemy and that they are waging war against the Thai state. The report portrays the Hmong as a tribe whose history has been associated with war. So it is quite convincing that they are now waging war against the Thai authorities, as is expressed in Paragraph 9: "...It's because the ethnic tribe of Hmong have been warriors from past to present...they fight like guerrillas...(...). 
Competing Discourses on Hilltribes: Media Representation of Ethnic Minorities in Thailand

They have caused a lot of trouble for the National Security Council for decades..."

Several terms of reference for the Hmong illustrate their characteristics as an aggressive tribe. These terms are, for example, Hmong warriors, Hmong movement, or even Hmong insurgents. The use of nominalized phrases emphasizes these categories. For example, the phrase "the production and distribution of amphetamines by the mountain Hmong" presupposes that the Hmong who live in the mountains (indicating that they are far away and can commit crimes easily) produce and distribute amphetamines. In the same way, the phrase "the trading road of undesirable goods of the Hmong" suggests that these people trade undesirable goods on this road. Upon reading the news, readers often take these nominalized phrases for granted, so the information conveyed is subtly accepted as part of the background knowledge on the part of the consumers.

However, after the almost ten-day coverage of the Phop Phra riot and subsequent incidents, a few special reports by both newspapers columnists and academics appeared in Phujadkan Raiwan and Krungthep Thurakit. These reports challenge the view that Hmong are drug traffickers. Instead, they propose that Hmong as well as other ethnic minorities have become victims of society and will remain so as long as the media continue to present what they believe to be true without thorough investigation (Chutima Suncharoen, 1998). Hilltribe people in this opposing discourse are "friends who live in the same society," who share our ideologies, and who deserve our attention and help (Ubonrat Siriyuwasak 1998).

\section{Thung Saeng Tawan's Discourse of Hilltribes}

The picture of happy children holding hands while dancing in the field is a familiar sight for Thung Saeng Tawan's young viewers who have to rise early in the morning on Saturdays "to follow the kids," to use the reporter's common phrase, to their communities. The verb 'to follow' conveys a figurative meaning here. As an outsider, the reporter needs local people to introduce her to their community. Children always play an important role in Thung Saeng Tawan's discourse. There may be a question why the team prefers children to adults, despite the fact that the latter should be more knowledgeable about their communities. To Niramol Methisuwakul, chief producer, children's perspectives are as important as those of others in the community. But she stresses that the team do not rely on these perspectives alone.

They do consult other sources. But most importantly they do not force the children to say things they want them to say. Niramol emphasizes that children's perspectives (and by implication native ones) and those of the production team are clearly demarcated.

$$
\begin{aligned}
& \text { Q: All of them (all the } \\
& \text { episodes) start with } \\
& \text { children, right? Hilltribe } \\
& \text { children are the ones who } \\
& \text { present information. }
\end{aligned}
$$


$\mathrm{N}$ : Yes, but our data are from several sources, such as NGOs, the government, parents, relatives, and community leaders. Then we synthesize from these perspectives, also taking into account the children's perspectives. When we have all the data, we start to outline a plot by looking at what the children say first. Afterwards, we may get other kinds of information. If it does not go..does not go along with (the children's perspectives), how much children know and understand, we'll let them say only that. Additional information we want to present is done through narration.

But in fact, it is almost impossible to say that the production team simply present facts, or in other words, they have no underlying ideologies for each production, as Niramol wants us to believe:

N: But in principle Thung
Saeng Tawan has no
hidden ideologies. We
simply think we will
narrate their ways of life
which we saw.

Based on the 'us' perspective, Thung Saeng Tawan depicts hilltribe people as members of the Thai nation-state. These people love and protect the environment as much as or even more than people in the city do. They are villagers with valuable traditions and plenty of advice for people from the mainstream culture. In this discourse, hilltribe children, like other children in the Thai nation-state, are simply dekdek 'children or kids,' as the opening of Withii Pakakeuyor 'Ways of the Karen', broadcast in January 1998, illustrates. (The words children or kids in (9) are translated from the Thai word dekdek.)

(9)

Narration:

Toong Saeng Tawan welcomes the year 1998 with stories from the highlands, the world of children. Children learn stories and gain knowledge both from everyday life and from home. While in school, each child has different subjects of interest, depending on their aptitude. There is a group of children. They are kids from the highlands at Mae Wang, Chiang Mai. They are Karen or another name Pakakeuyor. In this tribe-the children feel that if their ways of life, beliefs, and various aspects of their culture, what their ancestors told them, are not passed down, when they grow up, they will not know who they are, which tribe they belong to. So they want to preserve their culture. Today we will see villagers and school teachers help one another teach the kids. This is the school's local curriculum, and the kids love it very much.

Each production is full of children's voices telling their hopes and dreams, recounting their everyday experiences, 
and asking questions such as why hilltribe people are always blamed for deforestation, despite the fact that "we love forests". These voices are intertwined with those of local school teachers, community elders, parents, and, most importantly, the reporter. The reporter's story is woven with a layer of texts, as she reveals, consisting of official documents, research, teachers' reports, and NGO's work. These are complemented by personal experiences recounted by monks, and "friends in the media" who have seen what happened but are not in a position to present it. Hence, each production is a result of work and cooperation by those who share the ideology that hilltribe people protect the environment. This ideology is not directly asserted in the interview, but it is manifested in most of the productions.

Based on the idea that human beings must live together, even with limited natural resources, the program is aimed at telling stories of man, nature, and culture by introducing communities that can be considered environment protectors. Most of the 24 episodes on hilltribe people dealing with such groups as the Akha in khabuankan lai phi 'Driving Away Ghosts' and the Museur in dorkmai sai nam 'Flower, Sand, Water' focus on rituals. This is because, as Niramol puts it, rituals indicate "the strength of culture and community". The Lisu's ritual, sakorway-apologizing to nature with flowers, sand, and water-is a clear indication of how much this tribe cares for the fact that man must live in harmony with nature.

The discourse in which hilltribes are represented as people who live in the forests and live in harmony with nature helps counter-balance an image that these people are to be blamed for deforestation. The first episode on hilltribe cultures, Naaw Paa Son 'Cold Pine Forests,' features a Karen community in Mae Cham district, Chiang Mai. It illustrates how pine forests are important to Karen and how they preserve them. The theme of this specific production is conveyed mainly by a Karen girl named Sida. All images are carefully selected to stress the fact that Karen do not destroy forests. In one of the visual images, the reporter "follows the children" into the forest to watch how they search for fallen pine wood. This activity is presented to confirm the message that Karen do not cut trees. The story is full of questions the reporter asks the children. These questions introduce the native perspectives, their defensive voices in retorting to the stereotypic view that hilltribe people are selfishly destroying the country.

The following dialogue and narration at the end of the episode illustrate how Thung Saeng Tawan artistically incorporates the ideology that Karen do not destroy forests. Sida's answers strongly reflect how the natives feel when their forests are destroyed by outsiders:

(Niramol is interviewing Sida's grandfather $(G)$ and Sida (S) herself.)

$\mathrm{N}$ : How important are pine trees to our life?

G: Very important. Without lots of pine forests, we won't have water. Without pine wood, we must use oil. If you have money, 
you can buy it. If you don't, you must stay in the dark.

N: What about you, Sida? How important are the pine forests?

S: I have lived in the forests even since I was born. I don't have electricity like people in the city. I use the pine forests instead. We use maikea 'pine wood (Karen)' in place of electricity. And if the pine trees are cut down, the kids who are born after us will not get to see them again.

$\mathrm{N}$ : When lots of people cut trees, how do you feel?

S: I feel sad. I'm sad that the forests must be like this. I want the forests back. I don't want trees to be cut.

Narration (right after this dialogue):

Nowadays forests are destroyed We must help preserve them. Sida's grandfather teaches us that man and forests cannot live separately. Pakakeuyor must live in the forests. We are grateful to pine trees. They give us water. Karen have helped one another preserve them all along. There is an old Karen song saying "Don't admire other people's forests. We must preserve our forests. And then we'll have forests, water, clothes, and we can live on."
The dialogue in (10) and the narration in (11) strongly assert that forests are important to the Karen's life and, as Sida's response demonstrates, the natives are sad when trees are cut down, indicating they are not the ones who cut them.

The following dialogue in (12) in Saithan Haeng Khunkhao 'Stream of Mountain' is an additional voice asserting that hilltribe people should not be blamed for deforestation. This episode features Yao rituals which help protect the environment such as the ordination of trees and the feeding of ghosts who live in the forests.

(Niramol is talking to two Yao boys, $\mathrm{X}$ and $\mathrm{Y}$. $\mathrm{Y}$ is the one who replies to her questions)

$\mathrm{N}$ : What do you think when someone says hilltribe people cut trees and destroy forests?

Y: I'm sad. The lowlanders also cut them.

N: What about the highlanders? Did they cut a lot?

Y: Not really.

$\mathrm{N}$ : Really?

Y: Really.

$\mathrm{N}$ : In most cases what for?

Y: To do farming.

$\mathrm{N}$ : $\quad$ Is it necessary to fell big trees?

Y: No. Only the small ones are cut.

$\mathrm{N}$ : Why do we have to fell trees when we do farming? Is it possible for not doing farming?

Y: No. Without farming, there's nothing to eat. 


\section{$\mathrm{N}$ : What should hilltribe people and lowlanders do (about the situation)? \\ Y: We should protect forests. We should not destroy forests.}

In (12) the reporter's questions frame the child's answers. A message is conveyed that it is true that hilltribe people cut trees but they do so only because they have to, but even then they do not cut big trees to an extent that it can cause deforestation.

This episode also disputes the accusation that highlanders cause conflicts with Thai who live in the lowlands. The Yao and lowlanders join one another in the ceremony of extending life to the river. The narration (13) which begins this episode stresses this fact and asks those involved to shift the discourse of blaming to the one of helping one another in solving environmental problems.

Narration:

The Upper North is an important watershed area of Thailand. There are various kinds of problems which have caused watershed forests to be destroyed steadily. Nowadays several rivers are dry. These include the Mae Jai of Phayao. There is no time for us to quarrel with one another as to who destroys watershed forests. In the Baan Pang Puu Lau forest, Phayao Yao and lowland villagers join one another in conducting a ceremony to extend the life of the river. It's hoped that these watershed forest areas will sustain the Mae Jai river and help it to prosper.

Songs and music are important devices in Thung Saeng Tawan's discourse. Although they are most appropriate media to convey messages for children, and the production team explains that they are only one of several techniques to keep young audiences tuned in throughout the entire episode, I think songs function in more ways than that. They are most effective strategies to convey ideologies. It should be noted that apart from songs that are composed directly for each episode, there are songs in native languages which make the production seem more authentic. As Fairclough (1995:107) comments, "(A) chieving authenticity is also partly a matter of positioning the viewer through presupposition as someone who is already familiar with the culture and community depicted." Even though the production team are outsiders, they use this strategy to create an impression that they have known the community for a long time. Calling Karen Pakakeuyor, the term the natives call themselves, as is done in Withi Pakakeuyor or Naw Pa Son is also a strategy to convey a similar message.

\section{Competing Representations of Hilltribes, and the Politics of the Nation-State}

Interestingly, during the same year when news about Hmong became a big issue, a discourse of Karen also emerged. The Bangkok Post played an influential role in representing this group with a new identity - as members, or more appropriately, citizens of the nation-state who are aware of their own rights. Reports 
on Karen claiming land rights and taking democratic actions to protect their communities and the environment have appeared both in the form of news articles and opinion pieces in the daily Outlook section and the weekly Sunday Perspectives. To illustrate, the news extract in (14) reports an action by "Thai Karens" who appealed for help in their community.

\section{Wildlife Sanctuary \\ Lead Mine Faces Rising Opposition \\ Thai Karens Push For Its Closure. (Bangkok Post, 14 July 1998)}

The Klity lead mine which releases toxic waste water into Thung Yai Naresuan Wildlife Sanctuary must be closed, declared the Thai Karen in Western Thailand Group.

The group - a network of mostly forest-dwelling ethnic Karen in western Thailand-said they will mobilise support from environmental groups and Karen in other parts of the country in order to get the Klity mine closed. (Paragraphs 1-2)

This news article indicates that the Karen have a strong sense of community. They are aware that if they act as individuals, they may not be successful in realizing their goal. So they form a group and ask for help from other Karen communities and non-Karen environmental groups. Interestingly, the Karen in this news article are called "Thai Karen" to reflect the view that they are also Thai but with
Karen heritage. Another example of this discourse is found in Outlook (17 July 1998) in which the Karen at Samakae village in Kanchanaburi protected their forest from those who wanted to sell it to an open zoo operator. The report with the headline "United We Stand" illustrates a strong sense of cultural identity among the Karen and how they, contrary to stereotypes, take part in preserving national forests.

So although it is argued in Section 3 that hilltribe people, particularly Hmong, are represented in media discourse as agents of deforestation and drug traffickers and are represented in a way that reflects the ideology that these people are enemies of the state, there is also a discourse which opposes this ideology. This emerging discourse is quite recent and usually appears in the form of opinion pieces such as the ones we found in the Bangkok Post. Speaking on behalf of these indigenous people, these voices express the ideology that hilltribe people are also members of the nation-state but they are often victimized by Thai authorities, businessmen, and even the media.

The Karen in the news discourse are associated with distinctive identities - as a tribal group, thus subject to the same stereotypes as other ethnic minorities, and as members of the nation-state, the socalled Thai Karen. Though it may be concluded that both Karen and Hmong are generally represented as in opposition to the state, the media representation of the Hmong in 1998 gives a much more negative impression of this group than of the Karen. One journalist remarked: "After the coverage of the Hmong at Phop Phra, the image of the Hmong as 
associated with amphetamines is much worse - so bad that they can never be born again." That is, people will always remember the Hmong as those associated with drugs.

Presenting hilltribe stories from an insiders' perspective, Thung Saeng Tawan clearly demonstrates different ideologies from those of the general news discourse. Hilltribe people are no longer seen as those who destroy the environment. Moreover, the TV program employs several linguistic and extra-linguistic strategies to convey the perspective that hilltribe people belong to the same society as people in the mainstream culture. That Karen are great conservationists is the basis of this discourse. This is in sharp contrast with news articles in daily newspapers asserting that Karen are involved in national problems such as murder, mugging, and robbery, border problems with Burma, or constant conflicts with Thai villagers.

According to Chavarong Limpattamapanee (1999:171), several newspapers have become involved in the process of transforming Thailand into a civil society by acting as mouthpieces for the less fortunate so that their rights to land, work, and welfare can be protected. The type of news which concerns Karen found mainly in the Bangkok Post discussed above is a good sign that hilltribe people are using democratic means and taking part in the civil society movement. ${ }^{15}$ They are expressing their

15 I would expect that similar news is also reported in the Nation, but I have yet to investigate this. opinions publicly and dare to challenge the state if they feel their communities are in danger. Their cases illustrate that an awareness of one's own rights is built upon a strong sense of community and cultural identity.

Several journalists whom I interviewed think that the media representation of tribal minorities is much better than before, because people have more understanding of traditional problems associated with these minorities, viz. slash-and-burn farming and opium growing. But it must be admitted that there still remain two major flaws concerning news reports on hilltribes. First, front-page news stories employ violent words which denote strong racism. Hilltribe people are represented as the other whom Thai cannot trust. A clear example is when the Karen are called kariang naerakhun 'ungrateful Karen' who immigrated to Thailand and abused the kindness of those who gave them land and food (Thai Rath, 29 January 1991). Second, news reports are still dominated by perspectives of local officials whose voices are louder and sound more creditable. Besides, they speak the same language as journalists do. An interviewee comments that this problem concerns not only hilltribe people but also other members of the nation-state, especially Thai farmers who are facing a lot of unreported problems.

The situation on TV is quite promising.Thung Saeng Tawan on Channel 3 is a modern phenomenon of Thai TV which does more than just entertain viewers. It joins Khor Kid Duay Khon 'Let Me Think Too' on Channel 9, and Lan Ban Lan Muang 'House Ground, 
City Ground' on Channel 11 in addressing social concerns and letting local voices, including those of ethnic minorities, be heard publicly. However, several programs and documentary films broadcast on TV still present images of hilltribes as exotic objects of tourism or are used to promote the results of the state's welfare development projects. Broadcast in the early hours of Saturday mornings (7.30-8.00 hrs) and perceived as a program for children, Thung Saeng Tawan cannot deliver its message to a wide audience. Therefore, Thai conceptions of hilltribes are and will continue to be guided by what they read in the headlines and news reports. Whether or not hilltribe people are considered part of the nation-state depends largely on how the media, particularly the newspapers view them and how they voice themselves in this form of public discourse.

\section{Conclusion}

Based on the assumption that ideologies are embedded in discourse, this paper demonstrates conflicting ideologies concerning Northern ethnic minorities which underpin news discourse and Thung Saeng Tawan's discourse in contemporary Thai society. A number of lexical and discursive strategies are employed in conveying contrastive ideologies of these competing discourses. The news discourse is based on the metaphor that hilltribe people, particularly the Hmong, are enemies of the state, reflecting the 'them' perspective. On the other hand, Thung Saeng Tawan conveys an ideology that hilltribe people are also Thai citizens. Assuming the 'us' perspective, their discourse is based on the metaphor that hilltribe people are friends in society. The paper concludes with a discussion that racism still pervades Thai news discourse and this has an implication for the politics of the nation-state.

\section{References}

Archavanitkul, Kritaya, Poungomlee, Anuchat, Jarusomboon, Wanna, and chansomwong, Arphorn. 1999. Thai civil society: The making of Thai citizens. In Thai Civil Society: The Making of Thai Citizens, ed. by Anuchat Poungsomlee, and Kritaya Archavanitkul, pp. xxvii-lv. Bangkok: Research and Development of Civil Society Project, Mahidol University.

Blommaert, Jan. 1997. Introduction:Language and politics, language politics and political linguistics. In Political Linguistics, ed. by Jan Blommaert and Chris Bulcaen, pp. 1-10. Belgian Journal of Linguistics 11. Amsterdam: John Benjamins.

Fairclough, Norman. 1995. Media Discourse. London: Edward Arnold. 1992. Discourse and Social Change. Cambridge, UK: Polity Press.

Kress, G. and Hodge, R. 1979. Language as Ideology. London: Routledge and Kegan Paul.

Kuusisto, P, and Östman, J.O. 1997. The media as mediator: How foreigner discourse constructs ideology in Finnish newspapers. In Blommaert and Bulcaen (eds.).

Lee, David. 1992. Competing Discourses: Perspective and Ideology in Language. London: Longman.

Limpattamapanee, Chavarong. 1999. Bodbat Sumuanchon Kap Kanpattana Khwampenprachasangkhom (Role of media in the making of civil society). In Anuchat Poungsomlee and Kritaya Archavanitkul (Eds.), Thai Civil Society: The Making of Thai Citizens, Pp. 163-182.. Bangkok: Research 
and Development of Civil Society Project, Mahidol University.

Mehan, Hugh. 1997. The discourse of the illegal immigration debate: a case study in the politics of representation. Discourse \& Society 8.2: 249-270.

Rajah, Ananda. 1990. Ethnicity, nationalism and the nation-state: The Karen in Burma and Thailand. In Ethnic Groups across National Boundaries in Mainland Southeast Asia, ed. by Gehan Wijeyewardene. Singapore: Institute of Southeast Asian Studies.

Satayanurak, Atthajak. 1998. Hmong kap bank (Hmong and bank). Krungthep Thurakit, 5 August 1998, P. 15.

Silverstein, Michael. 1979. Language structure and linguistic ideology. In The Elements: A Subsession on Linguistc Units and Levels, ed. by R. Clyne, W. Hanks and C. Hofbauer, pp. 193-247. Chicago: Chicago Linguistic Society.

Siriyuwasak, Ubonrat. 1998. Thini yang $m i$ phunthii samrap.chao hmong, palonglisor, pakakoeyor? (Is there still place for.Hmong, Palong, Lisu, Pakhakoeyor?). Krungthep Thurakit, 11 September 1998, P. 2.

Suncharoen, Chutimaa. 1998. Pak Kham...Jamloei talordkan (Testimony...victims forever). Krungthep Thurakit, 10 September 1998, P.1.

Tapp, Nicholas. 1990. Squatters or refugees: Development and the Hmong. In Wijeyewardene (ed.), pp. 149-172. .1989. Sovereignty and Rebllion: The White Hmong of Northern Thailand. Singapore: Oxford University Press.

van Dijk, Teun A. 1995. Discourse semantics and ideology. Discourse \& Society 6.2: 243-289. van Dijk, Teun A., Ting-Toomey, Stella, Smitherman, Geneva, and Troutman, Denise. 1997. Discourse, ethnicity, culture and racism. In Discourse as Social Interaction Discourse Studies: A Multidisciplinary Introduction, Volume 2, ed. by Teun A. van Dijk, pp. 144-180. London: SAGE Publications. 